\title{
一般口演10
}

\section{全身姿勢の変化が身体重心動摇，頭位， 頭頸部筋筋活動，咬合に及ぼす影響}

\author{
Effect of changing body posture on body sway, \\ head posture, head and neck muscle activity and occlusion

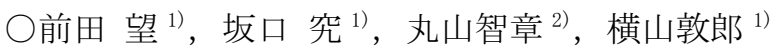 \\ Nozomi Maeda $^{1)}$, Kiwamu Sakaguchi ${ }^{1)}$, Maruyama Tomoaki ${ }^{2)}$, Atsuro Yokoyama ${ }^{1)}$ \\ 1) 北海道大学大学院歯学研究科口腔機能学講座口腔機能補綴学教室 \\ 2) 茨城工業高等専門学校 電気電子システム工学科所属 \\ 1) Department of Oral Functional Prosthodontics, Division of Oral Functional Science, Graduate School of \\ Dental Medicine, Hokkaido University \\ ${ }^{2)}$ Ibaraki National College of Technology
}

\section{I. 目 的}

これまでに，咬合不調和の是正と理学療法の併用によ り, 全身姿勢異常, 全身機能障害, 自律神経失調や不定 愁訴などの改善，さらには消失が認められたという症例 報告が数多くなされてきた ${ }^{1)}$. しかしながら, 顎口腔系 の変化と全身機能との関連性については未だに不明な点 が多く, エビデンスに基づいた臨床研究により, 客観的 に明示されるまでには至っていないのが現状である. 我々はこれまでに, 咬合と全身の関連性を客観的に評価 するために，下顎位と全身姿勢の関連性を示す基礎デー タを報告してきた ${ }^{2)}$.

咬合と全身の関連性を示す客観的評価方法の構築を目 的に, 本研究では, 咬合および身体重心動摇の評価に加 え, 頭位の動作解析および頭頸部筋群の筋電図学的評価 を同時に行った. 今回の発表では, 実験的に両足の踵を 挙上した場合, 身体重心動摇, 頭位, 頭頸部筋群および 咬合にどのような影響を及ぼすのかについて詳細な検討 を行ったので報告する.

\section{II. 方 法}

被験者は, 顎口腔系や平衡機能に機能障害を認めない 本学歯学部の学生から個性正常咬合者 13 名を選択した.

自然に直立した姿勢（以下，コントロールとする）と
両足の踵を挙上した姿勢における身体重心動摇, 頭位, 頭頸部筋群の筋活動量および咬合の評価を行った. 両足 の踵の挙上は，コントロールの姿勢から，両足の踵の下 に厚さ $10 \mathrm{~mm}$ のインソールを挿入して付与し, この姿勢 を両足挙上姿勢とした。

\section{1. 身体重心動摇と頭位の評価}

身体重心動摇の評価には, 足底圧分布測定システム (マ ットスキャン ${ }^{\circledR}$ ，ニッタ社製）を用いた。 パラメータに は，咬頭嵌合位における足底荷重中心移動の総軌跡長と 矩形面積, 前後・左右の足底荷重分布値を用いた。

頭位の動作解析には, の 3 次元動作解析システム（ひ まわり $\mathrm{GE} 60 / \mathrm{W}_{4} \mathrm{H}^{\circledR}$ ，ライブラリー社製）を用いて, 頭 部に設定した 4 測定点 (鼻根点, オトガイ点, 左右煩骨 点）の体幹に対する動作解析を行った. 頭位の変化を評 価するために，頭部の 4 測定点の重心を用いた．コント ロール時の重心を基準位として, 両足挙上姿勢時の重心 座標との差分を算出し, 解析パラメータとした.

なお，身体重心動摇と頭位のデータサンプリングは， 外部同期装置を用いて同時計測を行った.

\section{2. 頭頸部筋群の筋活動と咬合の評価}

頭頸部筋群の筋活動の評価には, 基礎医学研究システ ム $\left(B i o L o g D L-2000^{\circledR}, S \& M E\right.$ 社製）を用いて, 左右の咬 筋, 側頭筋, 胸鎖乳突筋, 僧帽筋の計 8 筋の計測を行っ た. データのサンプリングは, サンプリング周波数 $1 \mathrm{kHz}$ 


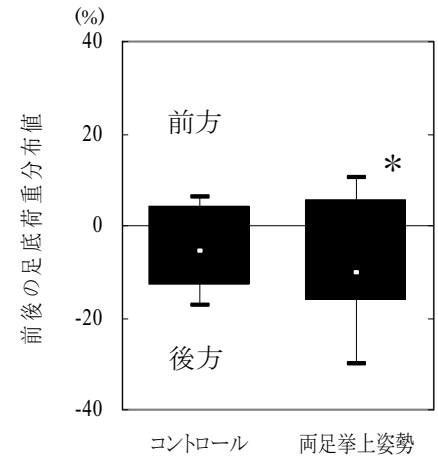

図1. 足底荷重分布值

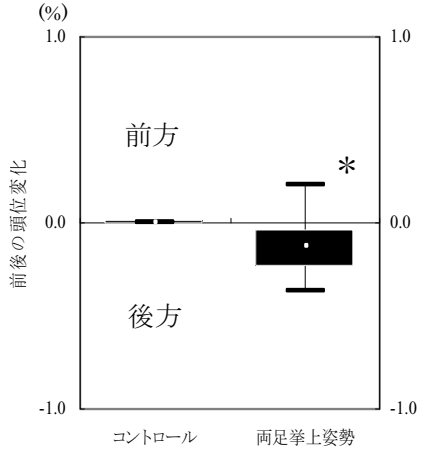

図 2. 頭位

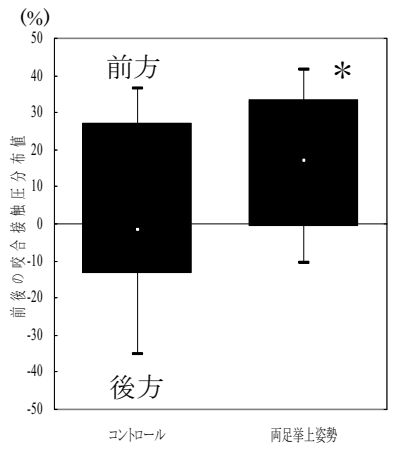

図 3. 最初の咬合接触

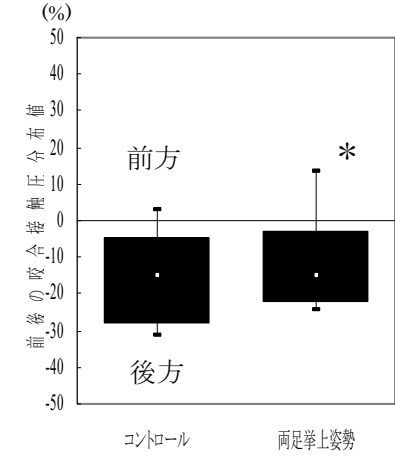

図 4. 咬頭嵌合位
とし，下顎安静位から咬頭嵌合位に至るまでを行った.

得られた各被験筋の表面筋電位は, 解析ソフト $\left(\mathrm{M}-\mathrm{Scope}{ }^{\circledR}, \mathrm{S} \& \mathrm{ME}\right.$ 社製) を用いて，バンドパスフィル ター (5〜 500 Hz) 処理後, 全波整流し, 積分值を求め筋 活動量とした. 各被験筋の最初の咬合接触と咬頭嵌合位 に至るまでの積分筋電位（IEMG）を求め, 解析パラメ ータとした。

咬合の評価には, 咬合接触圧分布測定システム（T ス キャン III ${ }^{\circledR}$ ，ニッタ社製）用いた．解析パラメータには, 咬合圧重心移動の総軌跡長と矩形面積, 最初の咬合接触 と咬頭嵌合位における前後・左右の咬合接触圧分布值を 用いた.

なお，頭頸部筀群筋活動と咬合のデータサンプリング は，外部同期装置を用いて同時計測を行った。

\section{III. 結果·考察}

\section{1. 身体重心動摇と頭位の評価}

\section{身体重心動摇}

両足挙上姿勢時の足底荷重中心移動の総軌跡長と矩形 面積は, コントロールと比較して変化は認められなかっ た. 一方, 咬頭嵌合位における前後の足底荷重分布值は, コントロールと比較して, 後方へ偏位した（ $\mathrm{p}<0.05 ）$ (図 1).

\section{頭位}

両足挙上姿勢時の咬頭嵌合位における頭位は，コント ロールと比較して，後方一偏位した（ $\mathrm{p}<0.05 ） （$ 図 2).

\section{2. 咬合と頭頸部筋群の筋活動量の評価} 頭頸部筋群の筋活動量

両足挙上姿勢時の最初の咬合接触と咬頭嵌合位におけ
る咬筋, 側頭筋, 胸鎖乳突筋の IEMG は, コントロール と比較して, 増加する傾向が認められた. また, コント ロールと比較して, 咬筋と側頭筋の IEMG の増加率は, 最初の咬合接触と咬頭嵌合位において, ともに側頭筋に 比べて咬筋の方が大きい傾向を示した.

咬合

両足挙上姿勢時の咬合圧重心移動の総軌跡長と矩形面 積は, コントロールと比較して, 変化は認められなかっ た. 最初の咬合接触と咬頭嵌合位における咬合接触圧分 布值は, コントロールと比較して, それぞれ前方に偏位 した $(\mathrm{p}<0.05)$ (図 3,4).

これらの結果から, 実験的に両足の踵を挙上すると, 咬合および身体重心動摇の安定性には影響を及ぼさなか った. しかし, 身体重心バランスと頭位は後方に, 咬合 接触は前方にそれぞれ偏位することが分かった。

以上のことから,実験的に両足の踵を挙上して全身姿 勢を変化させると, 全身姿勢, 頭位, および咬合に影響 を及ぼすことが示唆された。

\section{IV. 文 献}

1) Wright EF, Domenech MA, Fischer JR. Usefulness of posture training for patients with temporomandibular disorders. JADA 2000; 131: 202-210.

2) Sakaguchi K, Mehta N, Abdallah E et al. Examination of the relationship between mandibular position and body posture. J Craniomandib Pract 2007; 25: 237-249. 